\title{
Editorial
}

\section{Filosofar e Ensinar a Filosofar}

Com propósitos de promover o intercâmbio de ideias nascidas da intersecção entre Filosofia e Educação e de intensificar o debate sobre filosofias da educação e sobre o ensino de filosofia, a RESAFE dedica alguns de seus números à divulgação de textos da área apresentados em eventos acadêmicos na América do Sul. O presente número é composto integralmente por contribuições advindas de participantes do Grupo de Trabalho Filosofar e Ensinar a Filosofar, criado em 2006, no interior da Associação Nacional de Pós-graduação em Filosofia (ANPOF). Sete dos nove artigos que compõem este número foram originalmente apresentados durante o II Encontro Nacional do Grupo de Trabalho Filosofar e Ensinar a Filosofar, ocorrido na Universidade Gama Filho, no Rio de Janeiro, nos dias 10 e 11 de setembro de 2009. Escritos desde diversas perspectivas, os artigos ora publicados nos permitem conhecer como professores pesquisadores e estudantes de pós-graduação de distintas regiões do Brasil vêm pensando o filosofar e o ensinar a filosofar.

Questões referentes à própria definição de filosofia são analisadas por Gonzalo Armijos Palacios em seu artigo. De como ensinar o indefinível problematiza a noção de filosofia como ‘criação de conceitos' e discute obstáculos e desafios de seu ensino no atual contexto brasileiro.

Em Notas para uma filosofia contra o tempo, Ana Helena Amarante sugere que a atual discussão sobre a utilidade da filosofia seja ela mesma interrogada. Nietzsche e Deleuze inspiram a autora a reposicionar a filosofia e seu ensino no âmbito da produção afetiva, deslocando da questão 'para que serve?' à pergunta 'a quem aflige?'.

Leandro Cisneros, no artigo intitulado Ensino da filosofia: Pergunta filosófica, proposta metodológica e compromisso político, propõe que a Aufklärung seja compreendida como um projeto filosófico-político. A filosofia de Kant provê ao autor os instrumentos conceituais para pensar o exercício da filosofia não como uma propedêutica, e sim como uma das instâncias da formação e do exercício da própria política.

Relações entre filosofia e política são também investigadas por Arlindo Rodrigues Picoli. A crítica desponta como conceito central e é apresentada, a partir de uma abordagem foucaultiana, como uma ferramenta de liberdade. A conversão desta investigação teórica em práticas de ensino é de particular interesse do autor.

Apoiando-se igualmente nas idéias de Michel Foucault, a noção de resistência é utilizada por Elisete M. Tomazetti em sua interpretação de reflexões tecidas por professores e 
futuros professores de filosofia do Ensino Médio. Sobre ensino, aprendizagem e resistência na aula de Filosofia do Ensino Médio problematiza a impossibilidade indicada por estes sujeitos de realizar práticas docentes que efetivem o envolvimento do aluno com o pensar filosófico.

A controversa questão da avaliação em classes de filosofia é o tema central do artigo de Marinês Barbosa de Oliveira Dias. Em Avaliação em Filosofia sim! Por que não?, a autora apresenta as bases de sua proposta para a elaboração de instrumentos avaliativos do aprendizado filosófico na Educação Básica.

Com o objetivo de facilitar a aprendizagem de conceitos de lógica, Patrícia Del Nero Velasco vem desenvolvendo estratégias que possibilitem a estudantes do Ensino Médio aplicar os conteúdos aprendidos a materiais informais encontrados em seu cotidiano. O artigo Sobre o Lugar da Lógica na Sala de Aula oferece uma síntese dos trabalhos da autora.

Em O que "Ensinar Filosofia” quer dizer?, Arthur Meucci e Clóvis de Barros Filho apresentam suas reflexões sobre o que significa filosofar, seus pressupostos e sua prática. Os autores mostram como as respostas de estudantes, professores e pós-graduandos reafirmam aspectos implícitos por eles identificados no processo de ensino da filosofia.

O diálogo Górgias, de Platão, fornece a Vinicius B. Vicenzi um estimulante meio para pensar a relação do ensino de filosofia com interlocutores não-filósofos. A questão Como $a$ recepção da filosofia interfere no seu modo de ensino? encontra, em alguns interlocutores de Sócrates, pistas afetivas que podem auxiliar a prática educativo-filosófica em nossos dias.

Na seção de entrevistas, Filipe Ceppas, o atual coordenador do GT Filosofar e Ensinar a Filosofar da Associação Nacional de Pós-graduação em Filosofia (ANPOF), descreve alguns dos principais desafios do ensino de filosofia na atualidade, reflete sobre o lugar do pensamento filosófico-educativo na academia, provê um relato da história do GT e de suas próprias investigações como pesquisador da área.

Por fim, na seção dedicada a relatos de experiências, as autoras Elisete Medianeira Tomazetti, Katiuska Marçal e Tatiana de Melo Ribeiro discutem os resultados do projeto de pesquisa Filosofia, Cultura Juvenil e Ensino Médio desenvolvido no período de junho de 2004 a junho de 2009, na Universidade Federal de Santa Maria (UFSM), no Rio Grande do Sul.

Esperamos que a leitura dos trabalhos que compõem este décimo terceiro número da RESAFE seja inspiradora e inquietante, potencializadora de novos pensares sobre os laços que unem a filosofia e a educação.

Juliana Merçon 